\title{
STRENGTH OF CULTURE AND TRANSFER OF KNOWLEDGE IN ORGANIZATIONS
}

\author{
Nataša Pivec* \\ Vojko Potočan**
}

Received: 28. 3. 2021

Preliminary communication

Accepted: 31. 5. 2021

UDC 005.73(497.4),

DOI https://doi.org/10.30924/mjcmi.26.1.3

005.941(497.4)

\begin{abstract}
This paper analyses the effects of organizational culture on the transfer of knowledge in organizations. While prior literature has considered relations between individual classifications of organizational culture and the whole process of knowledge development, we focused our analysis on the dimension of cultural strength and its effects on the selected phase of knowledge transfer in organizations. Our study suggested that organizations need to analyse how weak and strong

data demonstrates that older respondents and employees in managerial positions are more prone to knowledge transfer. The analysis shows that the strength of organizational culture is positively and statistically significantly associated with knowledge transfer in organizations. The main practical implication of this study is our finding, which suggests that organizations need to further improve the transfer of knowledge through increasing the strength of organizational culture.
\end{abstract} organizational culture affects knowledge in organizations. The study drew upon the behavioural, organizational, and knowledge management theories and analysed answers from 138 respondents in Slovenian organizations. Analysing knowledge

Keywords: organizational behaviour, knowledge, organizational culture, transfer of knowledge, strength of culture

\section{INTRODUCTION}

Media headlines exposed the importance of learning and knowledge in modern organizations, facing the permanently changing environment (Nellen et al., 2020; Sayyadi, 2019). Growing organizations' interest in knowledge, related to operation and behavior, has led scholars to investigate the factors and supporting mechanisms that can drive knowledge development in organizations (De Long \& Fahey, 2000; Huang \& Huang, 2020).

Since the 1980s, management studies have debated the importance of knowledge in organizations for improving organizational results and their competitive position in the market (Hansen et al., 1999; Nonaka \& Takeuci, 1995). Under conditions of limited operation resources and tightened operating conditions in the global market, many authors recognized the new knowledge of organizations and their employees as promising solutions for modern organizations'

\footnotetext{
* Nataša Pivec, University of Maribor, Faculty of Economics and Business, Razlagova 14, 2000 Maribor, Slovenia. E-mail: natasa.pive@amis.net

** Vojko Potocan, University of Maribor, Faculty of Economics and Business, Department of Management and Organization, Razlagova 14, 2000 Maribor, Slovenia. Phone: + 38622290 250; e-mail: vojko.potocan@um.si
} 


\section{Journal of Contemporary Management Issues}

advancement (Harman \& Brelade, 2003; Nonaka, 2005).

Initial studies of knowledge in organizations have conceptualized the meaning of knowledge (Nonaka, 2005; Tobin, 2000), main factors of knowledge (Fang et al., 2013; Wang \& Noe, 2010), and basic concepts and models of knowledge (Argote \& Ingram, 2000; Nonaka \& Takeuci, 1995). They further highlighted that knowledge development contains acquiring, coding, storing, transferring, and using knowledge (Davenport \& Prusak, 1998; Dixon, 2017). In parallel, knowledge management began to develop as a comprehensive approach to dealing with knowledge (DeLuca \& Rubio, 2019; Pascale \& Athos, 1980).

Research findings on mechanisms supporting knowledge development in organizations are less uniform (Liu, 2020; Tobin, 2000). Empirical research has noted that technological, behavioral, and situational mechanisms, and associated factors, shape necessary preconditions for knowledge in organizations, but no agreement has been reached regarding their effect on the development and use of knowledge in organizations (Haamann \& Basten, 2019; Hansen et al., 1999). In particular, the effects of different behavior theories and behavior factors, like values, culture, ethics, and norms, have been less studied and explained (Dashpande, 2019; Nonaka, 2005).

The development of behavioral treatment of organizations also initiated the discussion about connections between organizational culture and knowledge in organizations (Jawadekar, 2011; Pascale \& Athos, 1980). This was followed by empirical research on the importance of several basic organizational cultures in comprehensive knowledge development, different types of knowledge, and possible solutions for acquiring and achieving individual goals in organizations (Abdelrahman \& Papamichail, 2016; Senge, 1995; Zheng et al., 2010). These studies have provided initial evidence about the meaning of organizational culture in knowledge development and established a broader picture of their relations (Deshpande, 2019; Nellen et al., 2020).

After the 1990s, research results and business practice drew organizations' attention to knowledge transfer as the main method of providing new or additional knowledge in organizations and as the central area of knowledge management (Fang et al., 2013; Tobin, 2000). Many scholars have focused their attention on demands and prerequisites for transfer, factors and capabilities of transfer, and models for its realization in diversified organizations (Dalkir, 2017; Hansen et al., 1999; Wang \& Noe, 2010), among others.

The most recent behavioral literature continues to analyze the meaning of different characteristics of culture, like heterogeneity, socialization, and strength for knowledge transfer in organizations (Abdelrahman \& Papamichail, 2016; Mahajan, 2019; Nellen et al., 2020), searching for methodological solutions, like models (Cameron \& Quinn, 1999; Deal \& Kennedy, 1998) and questionnaires (Brown, 1998; Pascale, 1984), to analyze it. Based on the results of the debates mentioned above, individual studies have analyzed the differences between the managerial and sociological understanding of culture, individual behavior models, and actual and perceived culture to understand the organizational culture (De Long \& Fahey, 2000; Harman \& Brelade, 2003; Zheng et al., 2010). In particular, the power of culture, a commonly used advisory solution to rapidly 
improve organizational results, has attracted research interest from managers in recent decades (Nellen et al., 2020; Zheng et al., 2010) and encouraged research on the links between changing organizational culture power (Pascale, 1984; Brown, 1998) and knowledge transfer as exchange or dissemination of knowledge (Argote \& Ingram, 2000; Rana et al., 2016). To sum up, the existing literature does not provide a comprehensive answer to how the strength of organizational culture is associated with knowledge transfer in organizations.

We complement previous organizational behavior studies by considering three behavior gaps in knowledge transfer in organizations. Firstly, we supplement previous studies by examining knowledge in organizations and analyzing the importance of knowledge transfer in the provision of knowledge (Nonaka, 2005; Wang \& Noe, 2010). Secondly, our analysis of the power of organizational culture and its effects on organizations and their knowledge (Nooshinfard \& NematiAnaraki, 2014; Tobin, 2000) broadened previous studies on organizational behavior (Deal \& Kennedy, 1998; De Long \& Fehey, 2000). Thirdly, we analyzed how organizational culture shapes knowledge transfer. Such an approach allowed us to assess the effect of the organizational culture on improving knowledge transfer in organizations as our unique contribution to behavioral literature (Pascale, 1984). Our findings have implications for business practices by suggesting that shaping organizational culture may enhance knowledge transfer.

\section{THEORETICAL BACKGROUND AND LITERATURE REVIEW}

\subsection{Knowledge in organizations}

\subsubsection{Development of knowledge in organizations}

Modern organizations operate in an environment of constant change; therefore, they must design their actions and behaviors to quickly respond and adapt to the environment (Hogan \& Coote, 2014; Rana et al., 2016). With limited resources and increasing competition in the market, learning and knowledge development can improve organizations' performance and ensure their long-term survival (Drucker, 1993; Liu, 2020; Senge, 1995).

According to Davenport and Prusak (2000), we considered organizational knowledge as an entity of experiences, values, information, and views of organizations and their employees who used organizations to develop their knowledge. Various definitions of organizational knowledge content are cited in the literature (Nellen et al., 2020; Nonaka, 2005), but most research in this area conceptualizes knowledge, based on Resource-Based Theory and Knowledge-Based Theory (Argote \& Ingram, 2000; Dalkir, 2017), which broadly define knowledge as either tacit, or explicit (Davenport \& Prusak, 2000; Nonaka \& Takeuchi, 1995; Polanyi, 2009). Past research has reported that about $95 \%$ of knowledge in an organization is in a tacit form, and about $5 \%$ of knowledge is then converted to explicit knowledge (Nellen et al., 2020).

In recent decades, numerous studies have confirmed the significant effect of knowledge on the organization and society's operation and behavior as a 


\section{Journal of Contemporary Management Issues}

whole (Argote \& Ingram, 2000; Dabic et al., 2017; Zheng et al., 2010). Following Schumpeter's (1934) presumption about the importance of knowledge for the economic growth of countries, Harman and Brelade (2003) noted that knowledge becomes an important competitive advantage of organizations, while Zheng et al. (2010) conceptualized knowledge as an important invisible resource of modern organizations.

In the literature, knowledge development is mainly defined as an area of continuous knowledge management of all types and forms of knowledge, in order to use the existing knowledge, develop new opportunities, and achieve goals (Fang et al., 2013; Tobin, 2000). Empirical studies have reported that knowledge management enables organizations to identify necessary knowledge, develop new knowledge, and transfer this knowledge to employees (Argote \& Ingram, 2000; Huang \& Huang, 2020; Leidner et al., 2006).

In most organizations, knowledge development begins with identifying, collecting, and organizing best practices and knowledge of individuals to clarify what we know and where that knowledge is in the organization (Argote \& Ingram, 2000; Hansen et al., 1999). In the next phase, the knowledge is transformed and stored in a format accessible to all employees who need it (Dalkir, 2017; Wang \& Noe, 2010). This is followed by the exchange or transfer of acquired knowledge to members of organizations to improve the organization's functioning by solving problems and creating new products and services (Leidner et al., 2006; Nellen et al., 2020). This process initiates a new cycle of knowledge development in organizations (O'Dell \& Grayson 1998; Zheng et al., 2010).

Individual authors have defined knowledge development activities differently
(Nonaka, 2005; Nellen et al., 2020), and combined them into different stages (De Long \& Fahey, 2000; Nonaka \& Takeuci, 1995). Literature has proposed several definitions of knowledge development, such as Davenport and Prusak Cycle, The Meyer and Zack Cycle, McElroy Cycle, Wiigu Cycle, and Dalkir (for individual definitions, see Dalkir, 2017; Nellen et al.,2020; Polanyi, 2009). Our research was grounded in the prevailing model of knowledge development, proposed by Davenport and Prusak (1998). Their model of knowledge development includes several phases, namely the acquisition, coding, storage, and knowledge transfer.

Recent studies of the phases of knowledge management have emphasized the central importance of the transfer of newly developed or existing knowledge to members of organizations for the effective use of knowledge and consequently for the achievement of the organization's goals (Dixon, 2017; Huang \& Huang, 2020; Nellen et al., 2020).

\subsubsection{Transfer of knowledge in organizations}

Knowledge transfer implies a process of exchanging and spreading knowledge to provide the necessary inputs to solve problems (Argote \& Ingram, 2000). In the 1990 s, organizations focused on transferring knowledge across the functional areas, formal units, and employees to improve acquisition, distribution, and availability of knowledge to organizational users (Argyris, 2001; De Long \& Fahey, 2000; Nonaka, 2005). In addition, scholars have highlighted the importance of knowledge transfer in providing the information to employees to guide their activities and collaborate with colleagues in problem-solving, in developing new ideas, or in implementing 
organizational policy (O’Dell \& Grayson, 1998; Senge, 1995).

Literature has reported that organizations might transfer knowledge through personalization and codification (Argote \& Ingram, 2000; Hansen et al., 1999). Personalization exposed the importance of personal transfer of tacit knowledge between people. In contrast, codification represents the transformation of knowledge into knowledge artifacts when knowledge needs to be shared with many people simultaneously (Brown, 1998; Osterloh \& Frey, 2000). Organizations, therefore, face the challenge of identifying the main factors that can affect the implementation of a transfer positively or negatively (Argote \& Ingram, 2000; Nonaka \& Takeuci, 1995) and develop the necessary support mechanisms for the actual implementation of knowledge transfer (Nonaka, 2005; Wang \& Noe, 2010).

Past studies of factors and constraints have highlighted the importance of individual, organizational, and technological factors and limitations of realizing knowledge transfer (De Long \& Fahey, 2000; Leidner et al., 2006; Zheng et al., 2010). Davenport and Prusak (1998) and Wang and Noe (2010) emphasized the importance of (1) organizational characteristics, especially relations between diverse parts of the organization and between the organization, the environment, and leadership, (2) groups' or teams' characteristics, especially relations between group members, groups overall, and social networks, and (3) technological characteristics of various information technologies, communication solutions, and technological-social interactions, especially pertaining to information technology for knowledge transfer. Among the most important constraints to the easy and rapid dissemination of knowledge among employees in organizations, according to studies of Davenport and Prusak (1998) and Nooshinfard and Nemati-Anaraki (2014), are lack of trust, differences in characteristics among members of an organization, ownership of knowledge, insufficient attention to the acquisition of new knowledge, and penalization of mistakes.

In addition, because knowledge in the organization is based on relations between members of the organization, organizations and their employees significantly influence knowledge transfer (De Luca \& Cano Rubio, 2019; Polanyi, 2009).

\subsection{Organizational culture and knowledge}

\subsubsection{Organizational culture}

The literature highlights the importance of behavior and behavioral factors, especially values, culture, ethics, and norms, in dealing with support mechanisms for developing knowledge in organizations (Nellen et al., 2020; Polanyi, 2009). Organizational culture is a complex and multidimensional construct that has attracted the research interest of academics and practitioners in the last decades (Hogan \& Coote, 2014; Schein, 1985).

The history of organizational culture is a long one and includes "studies conducted before the 1980s mainly by social science scholars" (Huang \& Huang, 2020; Schein, 1985), "conceptualization of organizational culture as an important behavior factor of organizations in the 1980s" (Cameron \& Quinn, 1999; De Long \& Fahey, 2000), and "studies conducted in 1990s and later" (Hansen et al., 1999; Hogan \& Coote, 2014). Scholars from social sciences, especially sociology and psychology (Schein, 1985; Wang \& Noe, 2010), have significantly contributed to this study area. 


\section{Journal of Contemporary Management Issues}

Reviews of culture have established culture as a whole of rituals and meanings and considered differentiation, fragmentation, tolerance, and control of culture in the organization (Argote \& Ingram, 2000; Cameron \& Quinn, 1999; Schein, 1985). At the beginning of the 1980s, growing societal expectations (Dixon, 2017; Tobin, 2000) triggered research on the effects of organizational culture on understanding organizational behavior (Nellen et al., 2020; Wang $\&$ Noe, 2010). Among them, it is necessary to highlight the findings of Schein (1985, p. 12), who defined culture as "a set of implicit assumptions held by members of a group that determines how the group behaves and responds to its environment," and Cameron and Quinn (1999, p. 7) who defined culture as "a set of values, beliefs, and hidden assumptions that organizational members have in common". The above-mentioned conceptualization of organizational culture forms a modern understanding of organizational culture and enables further research into the importance and role of culture for behavior, operation, and outcomes of organizations (Hansen et al., 1999; Zheng et al., 2010). Management and organizational research of culture after 1990 focused on analyzing relations between organizational culture, especially their effective, intuitive, and impulsive factors, and models of ethical behavior of organizations (Harman \& Brelade, 2003; Wang \& Noe, 2010).

Organizational culture, viewed as a whole, may vary along different dimensions (Deal \& Kennedy, 1998; De Long \& Fahey, 2000; Schein, 1985, including heterogeneity, socialization, and strength of culture in organizations (Brown, 1998; Nellen et al., 2020; Pascale, 1984). In our consideration of organizational culture, we focused on a predominant model of cultural organizations in management proposed by Deal and Kennedy (1998) and the socialization model of culture proposed by Brown (1998). We measured the strength of culture with a questionnaire developed by Pascale (1984). Brown (1998) framed the strength of culture as a product of the interactions of the widespread distribution of beliefs, the strength of consensus and the intensity with which beliefs are held, or the strength of feeling. Despite the variations in cultural' strength, the literature has centered on creating a strong culture and addressing its effects on individual parts, actions, decisions, and behaviors in an organization (Brown, 1998; Cameron \& Quinn, 1999; Pascale, 1984). In organizational practice, strong organizational culture is intended to engender commitment, dedication and devotion, enthusiasm, and passion among organizational employees, which, importantly, affect behavior (De Long \& Fahey, 2000; Nellen et al., 2020). On the contrary, individual studies have pointed out the possible shortcomings of a strong culture, highlighting the requirements of organizations to obtain complete loyalty and compliance from their member and attempts to impose organizational culture on members as the dominant basis of their identity (Brown, 1998; Cameron \& Quinn, 1999; Hansen et al., 1999).

In recent decades, scholars have viewed organizational culture as a prerequisite for developing a learning organization and the effect of culture on the development of knowledge, especially knowledge transfer (Dabic et al., 2017; Liu, 2020; Polanyi, 2009). Organizational culture influences transfer of knowledge in various ways. The literature most often cites the work of Davenport and Prusak (2000), and De Long and Fahey (2000), which presumed that knowledge is crucial for the organization, defining the relationship between knowledge at the member level and organization levels, developing appropriate social 
interaction in the organization, and enhancing the willingness of employees to use new knowledge.

\subsubsection{Organizational culture and transfer of knowledge}

Latest management studies have conceptualized the importance, extent, and societal advantages of organizational culture for sharing or disseminating knowledge in organizations (Abdelrahman \& Papamichail, 2016; Nonaka, 2005; Zheng et al., 2010).

After the 1990s, researchers expanded the discussion of culture and knowledge transfer to limitations of humans' abilities and competencies to transfer knowledge (Nonaka \& Takeuci, 1995; O’Dell \& Grayson, 1998). Thus, studies have addressed how individuals feel about sharing knowledge (Tobin, 2000; Wang \& Noe, 2010), how employees respond to different solutions for limited transfer and dissemination of knowledge in organizations (Harman \& Brelade, 2003; Tobin, 2000), how organizations support employee commitment for knowledge exchange (Hansen et al., 1999; Hogan \& Coote, 2014), and how employees can develop their willingness and skills to share knowledge (Argote \& Ingram, 2000; Argyris, 2001).

The literature has highlighted the importance of organizational culture power (Brown, 1998; De Long and Fahey, 2000) to achieve the desired results of knowledge transfer in organizations (Deshpande, 2019; Pascale, 1984). Thus, several studies have reported that employees expect and prefer a stronger organizational culture (De Long \& Fahey, 2000; Tobin, 2000); employees believe that strong culture supports their knowledge transfer (Argote \& Ingram, 2000; Brown, 1998) and that stronger organizational culture accelerates the transfer of knowledge in organizations (Hansen et al., 1999; Zheng et al., 2010). In addition, several studies have noted that a strong organizational culture increases employee commitment and readiness to actively participate in the organization's social functioning and advanced level of responsible social relations in organizations (Dabic et al., 2017; Nellen et al., 2020) that improve knowledge transfer.

Attempts to explain the relationship noted that weak culture might affect the knowledge transfer in organizations (Harman \& Brelade, 2003; Pivec \& Potocan, 2015; Zheng et al., 2010). One group of researchers presume that a weak culture is suitable for organizations with lower cultural heterogeneity and for organizations that need to change the culture constantly and rapidly (Argote \& Ingram, 2000; Brown, 1998) and that knowledge transfer in such organizations is primarily dependent on their functional characteristics (Brown, 1998; Zheng et al., 2010). In addition, individual studies have highlighted the importance of employee social development (Deshpande, 2019; Hogan \& Coote, 2014) and the growing moral commitment of employees (Fang et al., 2013; Hansen et al., 1999) to transfer knowledge to such organizations. In contrast, several studies have reported that a weak organizational culture reduces the ability of organizations to develop loyalty and social commitment among members of organizations, consequently decreasing the transfer of knowledge (Fang et al., 2013; Wang \& Noe, 2010).

Based on the studies on the relationship between the strength of organizational culture and knowledge transfer processes in organizations (Davenport \& Prusak, 2000; De Long \& Fahey, 2000; Nellen et al., 2020), we formed our research assumption about the importance of strong organizational 


\section{Journal of Contemporary Management Issues}

culture for knowledge transfer. We, therefore, proposed the following:

H1: Strong organizational culture has a positive and statistically significant effect on increasing knowledge transfer in organizations.

\section{METHODS}

\subsection{Statistical population and sample}

The population included medium and large Slovenian organizations. Based on stratified sampling, we included 607 organizations, 300 medium and 307 large, to the survey. The primary data were collected in February 2019. Within the planned period of 30 days, we received 144 questionnaires, by using the Lime Service online database, of which six were incomplete and had to be excluded them from further analysis. The final sample consisted of 138 organizations, 84 were medium-sized and 54 large organizations, resulting in a $22.73 \%$ response rate.

The structure of respondents by gender showed that out of 138 respondents, 78 were women $(60 \%)$, and 60 were men $(40 \%)$. In terms of age, most respondents were between 31 and 50 years of age, most of them with a university degree. In terms of length of service, most respondents worked in the organization for more than 25 years, mostly in the human resources department. The sample consisted of 84 medium $(61 \%)$ organizations and 54 large $(39 \%)$ organizations. The structure of organizations by ownership included 62 (45\%) state-owned organizations, 48 (35\%) privately owned, and $28(20 \%)$ with mixed ownership. Concerning the legal form, 52 $(38 \%)$ organizations included in the sample belonged to limited liability companies, 42 (30\%) were public institutions, 37 (27\%) were joint-stock companies, $6(4 \%)$ were limited partnerships, and the survey also included a sole proprietor $(1 \%)$.

\subsection{Research instrument}

To collect the data, we used a structured questionnaire, measuring: (1) demographic characteristics of survey participants and their organizations, (2) organizational culture, by using 16 items adopted from Pascale (1984), (3) knowledge development, including statements about knowledge acquisition, coding, storing, transfer, and use, and (4) questions related to the learning centers in organizations. All items in parts 2 through 4 were designed to allow the respondents to express their level of agreeing or disagreeing with each statement. A Likert scale with five response options was used: (1) I totally disagree; (2) I don't agree; (3) I neither agree nor disagree; (4) I agree; (5) I totally agree (Warner, 2013, p. 9-10). In our research, we used the data from the second and third parts of the questionnaire.

\subsection{Measures}

We included two latent variables to the survey: (1) Three items measured knowledge transfer. A sample item was, "In our organization, we have developed a system of mentoring of a new co-worker." Cronbach's reliability of this variable was .702 , (2) Strength of organizational culture comprised of 16 items. A sample item was, "In our organization, all employees can express values, which are accepted in the organization." Cronbach's reliability of this variable was .902 .

Demographic variables were measured as follows. Respondents indicated the age group to which they belong, provided 
information about their gender, selected their completed level of their education and working position, as well as provided information on organizational size.

\subsection{Data analysis}

Our analysis comprised the following steps. Firstly, we outlined the elements of descriptive statistics, including mean values, standard deviations, and zero-order correlations between variables used in the research. Secondly, we conducted the hierarchical regression analysis. In the first phase of the analysis, we entered the control variables, namely age, gender, level of education, position in the organization, and organizational size. In the second phase, we entered variables measuring the strength of organizational culture. All the calculations were performed by IBM SPSS 20 .

\section{RESULTS}

The descriptive statistics, including mean values, standard deviations, and zeroorder correlations between variables used in the research, are summarized in Table 1.

Table 1. Mean values, standard deviations, and zero-ordered correlations

\begin{tabular}{|l|l|l|l|l|l|l|l|l|}
\hline \multicolumn{1}{|c|}{ Variable } & \multicolumn{1}{c|}{ M } & \multicolumn{1}{c|}{ SD } & \multicolumn{1}{c|}{$\mathbf{1}$} & \multicolumn{1}{c|}{$\mathbf{2}$} & $\mathbf{3}$ & $\mathbf{4}$ & $\mathbf{5}$ & $\mathbf{6}$ \\
\hline 1. Gender & 1.40 & .491 & 1 & & & & & \\
\hline 2. Age & 2.91 & .850 & -.056 & 1 & & & & \\
\hline 3. Education & 3.85 & 1.066 & $.214^{*}$ & .018 & 1 & & & \\
\hline $\begin{array}{l}\text { 4. Position in } \\
\text { organization }\end{array}$ & 1.67 & .470 & -.128 & $-.309^{* * *}$ & $-.332^{* * *}$ & 1 & & \\
\hline $\begin{array}{l}\text { 5. Organizational } \\
\text { size }\end{array}$ & 1.39 & .490 & $-.167^{*}$ & .152 & -.025 & -.012 & 1 & \\
\hline $\begin{array}{l}\text { 6. Organizational } \\
\text { culture }\end{array}$ & 3.06 & .589 & .071 & .098 & $.212^{*}$ & $-.247^{* *}$ & .022 & 1 \\
\hline $\begin{array}{l}7 . \text { Knowledge } \\
\text { transfer }\end{array}$ & .010 & .991 & .082 & $.244^{* *}$ & .114 & $-.266^{* *}$ & .082 & $.683^{* * *}$ \\
\hline
\end{tabular}

${ }^{*} p<.05 ;{ }^{* *} p<.01 ;{ }^{* * *} p<.001$

The results of hierarchical regression analysis of the effect organizational culture on knowledge transfer, while controlling for control variables, are summarized in Table 2. 


\section{Journal of Contemporary Management Issues}

Table 2. Hierarchical regression analysis

\begin{tabular}{|l|r|r|}
\hline \multicolumn{2}{|c|}{ Model 1 } & Model 2 \\
\hline 1.Demographic and organizational variables & .071 & .057 \\
\hline Gender & $.180^{*}$ & $.156^{*}$ \\
\hline Age & .035 & -.061 \\
\hline Education & $-.189^{*}$ & -.067 \\
\hline Position in organization & .065 & .051 \\
\hline Organizational size & & \\
\hline 2. Organizational culture & & $.659^{* * *}$ \\
\hline Strength of organizational culture & 138 & 138 \\
\hline$N$ & .109 & .508 \\
\hline $\mathrm{R}^{2}$ & $3.240^{*}$ & $22.566^{* * *}$ \\
\hline Model F & \multicolumn{2}{|c|}{} \\
\hline
\end{tabular}

${ }^{*} p<.05 ;{ }^{* *} p<.01 ;{ }^{* * *} p<.001$

The hierarchical regression analysis results revealed that the strength of organizational culture is positively and statistically significantly associated with knowledge transfer $(\beta=.659 ; p<.001)$. This provides support for Hypothesis 1.

Among the control variables in the analysis, age had the most notable effect on knowledge transfer $(\beta=156 ; \mathrm{p}<.05)$, indicating that older respondents are more prone to transfer knowledge compared to the younger ones. The position in the organization is another significant variable worth mentioning $(\beta=-.189 ; p<.05)$, indicating that employees in managerial positions are more prone to knowledge transfer.

\section{DISCUSSION}

This study examined the effect of the strength of organizational culture on knowledge transfer in organizations and revealed a strong, positive, and statistically significant relationship between organizational culture and knowledge transfer. This

suggests that knowledge transfer is higher within organizations with stronger organizational cultures compared to organizations with weaker organizational cultures. Organizational culture accounted for almost $40 \%$ of the variance in knowledge transfer, supporting the presumptions about the importance of strong organizational culture for knowledge transfer in today's organizations (Potocan et al., 2020; Weightman, 2019)

In terms of a significant effect of personal and organizational demographic variables, older respondents are more prone to transfer knowledge, compared to the younger ones (Osterloh \& Frey, 2000; Popovic \& Nedelko, 2018). This is expected, as senior employees are usually transferring knowledge to lower-ranking employees via mentoring, coaching, and other activities (Cresnar \& Nedelko, 2020; O’Dell \& Grayson, 1998). From the viewpoint of the respondent's position in an organization, employees in managerial positions are more prone to knowledge transfer, compared to other employees. Again, this is in line with expectations, as traditionally, employees 
in managerial positions have been coaching and mentoring those in non-managerial positions and possess the most important knowledge in the organization (Argyris, 2001; Dabic et al., 2021).

\subsection{Theoretical implications}

The main theoretical implication of this study is that it has empirically verified the association between the strength of organizational culture and knowledge transfer in organizations and that it has confirmed theoretical assumptions (Fang et al., 2013; Hogan and Coote, 2014) about the substantial importance of organizational culture for knowledge transfer. The obtained results provide a fertile ground for further research on the effect of organizational culture on knowledge transfer in organizations.

\subsection{Practical implications}

This study has several practical implications. Organizations and their managers should capitalize on the substantial importance of organizational culture in the knowledge transfer process. Managers should recognize the organizational culture as one of the key drivers of the knowledge transfer process, as fostering organizational culture will improve the knowledge transfer process. Organizational culture can be enhanced by conducting team buildings, workshops, active seminars, etc.

Knowledge transfer should also be fostered among younger employees, as they are less prone to sharing. Increasing the readiness of younger employees to transfer the knowledge is especially important today, as younger employees may have better knowledge of "how to work in the digitalized environment." Therefore, inverse-coaching should also be stimulated in organizations, including additional workshops, in-service training, new reward systems for (inverse) coaching, etc. (Dabic et al., 2017). As employees in managerial positions are more prone to transfer knowledge, managers should become aware that the organizational environment requires intensive knowledge transfers among employees (Leidner et al., 2006; Rashad \& Nedelko, 2020). Accordingly, managers should also encourage employees in nonmanagerial positions to actively participate in the knowledge transfer processes.

The study results can inform various political, educational, and organizational actors responsible for developing a "creative society" and transfer of knowledge in society and enhance the abilities and competencies of people for innovative working (Dabic et al., 2017; Liu, 2020; Senge, 1995).

\subsection{Limitations}

This study has some limitations. Firstly, the research was done in a specific environment of Slovenia defined by country-specific historical, economic, and cultural development, which may have implications for the results and limit the broader generalization of research findings to other countries with different development trends (Potocan et al., 2020). The research followed Deal and Kennedy's (1998) classification of organizational culture and Pascale's (1984) study of strength of culture, while we did not consider other typologies of organizational culture. Secondly, we focused only on analyzing the transfer of knowledge, and we did not address other phases of knowledge development (De Luca \& Cano Rubio, 2019). Thirdly, we used a self-assessment approach, where respondents expressed their opinions of knowledge transfer. Fourthly, a minor limitation concerns the structure of the sample. We used a convenience sample selection method to select 


\section{Journal of Contemporary Management Issues}

medium and large organizations with particular types of ownership and legal forms; hence, the results may not generalize to other organizations (Potocan et al., 2020).

\subsection{Future research}

Our results generate directions for future research. Firstly, organizational culture should be examined with a typology different from the one used in this paper (De Long \& Fahey, 2000) to verify the pattern of the results. Secondly, the effect of organizational culture on all phases of the knowledge management process should be explored (Davenport \& Prusak, 2000). Thirdly, our research should be replicated in other societies to validate our findings (Dabic et al., 2017; Potocan et al., 2020). Fourthly, further studies could try to determine whether personal values and general value orientation have some implications for the knowledge transfer process.

\section{CONCLUSIONS}

Knowledge has become one of the key drivers of organizational success in today's environment. To reap the benefits of employees' knowledge in organizations, a knowledge transfer process is necessary to share useful knowledge with as many organizational members as possible. Building on the assumptions about the effect of organizational culture on the knowledge transfer process, we empirically proved that organizational culture has a strong, positive, and statistically significant influence on the knowledge transfer process. Besides that, it is evident that older employees and employees in managerial positions are more prone to knowledge transfer.

These findings provide fertile ground for further research and a solid base for streamlining activities in order to foster the knowledge transfer process, especially via strengthening organizational culture.

\section{REFERENCES}

1. Abdelrahman, M., \& Papamichail, K. (2016). The Role of Organizational Culture on Knowledge Sharing by Using Knowledge Management Systems in MNCs. Journal on Information Systems, 11 (2), 22-42.

2. Argote, L., \& Ingram, P. (2000). Knowledge transfer: A Basis for Competitive Advantage in Firms. Organizational Behavior and Human Decision Processes, 82 (1), 150-169.

3. Argyris, C. (2001). On organizational learning. Oxford: Blackwell Business.

4. Brown, A. (1998). Organization Culture. London: Financial Times.

5. Cameron, K., \& Quinn, R. (1999). Diagnosing and Changing Organizational Culture: Based on the Competing Values Framework. Reading: Addison-Wesley.

6. Cresnar, R., \& Nedelko, Z. (2020). Understanding future leaders: How are personal values of generations $\mathrm{Y}$ and $\mathrm{Z}$ tailored to leadership in Industry 4.0? Sustainability, 20 (12), 1-19.

7. Dabic, M., Potocan, V., \& Nedelko, Z. (2017). Personal Values Supporting Enterprises' Innovations in The Creative Economy. Journal of The Knowledge Economy, 8 (4), 1241 - 1261.

8. Dabic, M., Stojcic, N., Simic, M., Potocan, V., Slavkovic, M., \& Nedelko, Z. (2021). Intellectual Agility and Innovation in Micro and Small Businesses: The Mediating Role of Entrepreneurial Leadership. Journal of Business Research, 123, 683-695. 
9. Dalkir, K. (2017). Knowledge management in theory and practice. Cambridge: Massachusetts Institute of Technology.

10. Davenport, T., \& Prusak, L. (2000). Working knowledge: How organizations manage what they know. Boston: Harvard Business School Press.

11. Deal, T., \& Kennedy, A. (1998). Corporate Culture: The Rites and Rituals of Corporate Life. London: Penguin.

12. De Long, D., \& Fahey, L. (2000). Diagnosing cultural barriers to knowledge management. Academy of Management Executive, 14 (4), 113-127.

13. De Luca, P., \& Cano Rubio, M. (2019), The curve of knowledge transfers: A theoretical model. Business Process Management Journal, 25 (1), 10-26.

14. Deshpande, A. (2019). Concurrent Engineering, Knowledge Management, and Product Innovation. Journal of Operations and Strategic Planning, 1 (2), 204-231.

15. Dixon, N. M. (2017). The organizational learning cycle: How we can learn collectively. London, New York: Routledge.

16. Drucker, F. P. (1993). Managing for the future: The 1990s and beyond. New York: Truman Talley Books.

17. Fang, S. C., Yang, C.W., \& Hsu, W. Y. (2013). Inter-organizational knowledge transfer: The perspective of knowledge governance. Journal of Knowledge Management, 17 (6), 943-957.

18. Haamann, T., \& Basten, D. (2019). The role of information technology in bridging the knowing-doing gap: An exploratory case study on knowledge application. Journal of Knowledge Management, 23 (4), 705-741.
19. Hansen, T., Nohria, N., \& Tierney, T. (1999). What's your strategy for managing knowledge? Harvard Business Review, 77, 106-116.

20. Harman, C., \& Brelade, S. (2003). Doing the Right Thing in a Knowledge Transfer. Knowledge Management Review, 6 (1), 28-31.

21. Hogan, S. J., \& Coote, L. V. (2014). Organizational culture, innovation, and performance: A test of Schein's model. Journal of Business Research, 67 (8), 1609-1621.

22. Huang, C., \& Huang, S. (2020). External and internal capabilities and organizational performance: Does intellectual capital matter? Asia Pacific Management Review, 25 (2), 111-120.

23. Jawadekar, W.S. (2011). Knowledge Management: Text \& Cases. New Delhi: Tata McGraw-Hill.

24. Leidner, D., Alavi, M., \& Kayworth. T. (2006). The Role of Culture in Knowledge Management: A Case Study of Two Global Firms. International Journal of e-Collaboration, 2 (1), 1-24.

25. Liu, S. (2020). Knowledge Management: An Interdisciplinary Approach for Business Decisions. London: Kogan Page.

26. Mahajan, A. (2019). Relationship of Talent Management with Organizational Culture: A Discussion Paper. Indian Journal of Industrial Relations. 54 (3), 471-481.

27. Nellen, L., Gijselaers, W., \& Grohnert, T. (2020). A Meta-Analytic Literature Review on Organization-Level Drivers of Team Learning. Human Resource Development Review, 19 (2), 152-182.

28. Nonaka, I. (2005). Knowledge Management: Critical Perspectives on 


\section{Journal of Contemporary Management Issues}

Business and management. New York: Routledge.

29. Nonaka, I., \& Takeuci H. (1995). The knowledge-creating company. How Japanese Companies create the Dynamics of Innovation. New York: Oxford University Press.

30. Nooshinfard, F., \& Nemati-Anaraki, L. (2014). Success factors of inter-organizational knowledge sharing: a proposed framework. The Electronic Library, 32 (2), 239-261.

31. O’Dell, K., \& Grayson. C.J. (1998). If Only We Knew What We Know: Identification and Transfer of Internal Best Practices. California Management Review, 40 (3), 154-174.

32. Osterloh, M., \& Frey, B. (2000). Motivation, knowledge transfers and organization forms. Organizational Science, 11 (5), 538-550.

33. Pascale, R. (1984). The paradox of "Corporate culture": Reconciling ourselves to socialization. Stanford University: Graduate School of Business.

34. Pascale, R., \& Athos, A. (1980). The art of Japanese Management. London: Penguin.

35. Pivec, N., \& Potocan, V. (2015). The influence of employees' values on the acquisition of knowledge in organizations. Our Economy, 61 (6), 19-27.

36. Polanyi, M. (2009). The Tacit dimension. Chicago, London: The University of Chicago Press.

37. Popovic, T., \& Nedelko, Z. (2018). Social responsibility and strategic orientation of higher education - Cases of Croatia and Bosnia and Herzegovina. Management, 23 (2), 123-139,

38. Potocan, V., Mulej, M., \& Nedelko, Z. (2020). Society 5.0: Balancing of
Industry 4.0, Economic Advancement and Social Problems. Kybernetes, 1-18.

39. Rana, S., Ardichvili, A., \& Polesello, D. (2016). Promoting self-directed learning in a learning organization: Tools and practices. European Journal of Training and Development, 40 (7), 470-489.

40. Rashad, W., \& Nedelko, Z. (2020). Global sourcing strategies: A framework for lean, agile, and leagile. Sustainability, 12 (17), 1-29.

41. Sayyadi, M. (2019). How effective leadership of knowledge management impacts organizational performance. Business Information Review, 36 (1), 30-38.

42. Schein, E. (1985). Organizational culture and leadership. San Francisco: Jossey-Bass.

43. Schumpeter, J. (1934). The theory of economic development. Cambridge, MA: Harvard University Press

44. Senge, P. M. (1995). The fifth discipline field book: strategies and tools for building a learning organization. London: Nicholas Brealey.

45. Tobin, D. R. (2000). All Learning is self-directed: how organizations can support and encourage independent learning. Alexandria: American Society for training and development.

46. Wang, S., \& Noe, R. (2010). Knowledge sharing: A review and directions for future research. Human Resource Management Review, 20 (2), 115-131.

47. Weightman, J. (2019). Business ops: Hiding knowledge management practices in plain sight. Business Information Review, 36 (4), 188-195.

48. Zheng, W., Yang, B., \& McLean, G. (2010). Linking organizational culture, 
structure, strategy, and organizational effectiveness: Mediating role of knowledge. Journal of Business Research, 63 (7), 763-771.

\title{
SNAGA ORGANIZACIJSKE KULTURE I TRANSFER ORGANIZACIJSKOG ZNANJA
}

\begin{abstract}
Sažetak
Uovom se radu analizira utjecaj organizacijske kulture na transfer organizacijskog znanja. Dok su se u ranijoj literaturi razmatrali odnosi između individualnih tipova organizacijske culture i cjelovitog procesa stvaranja znanja, svoju analizu usmjeravamo na dimenziju snage kulture i njezino djelovanje na izrabranu fazu prijenosa znanja. Iz rada proizlazi da organizacije trebaju analizirati kako slaba, odnosno snažna organizacijska kultura utječe na organizacijsko znanje. Na temelju teorija iz područja razumijevanja ponašanja, organizacije i upravljanja znanjem te analize 138 ispitanika iz slovenskih

organizacija, utvrđeno je da su stariji ispitanici, kao i zaposlenici na menadžerskim pozicijama skloniji transferu znanja. Snaga organizacijske kulture je pozitivno i statistički značajno povezana s prijenosom organizacijskog znanja. Ključna praktična implikacija ovog rada je rezultat, koji govori da organizacije trebaju unaprijediti prijenos znanja putem povećanja snage kulture.

Ključne riječi: organizacijsko ponašanje, znanje, organizacijska kultura, prijenos znanja, snaga organizacijske kulture
\end{abstract}

